\title{
A new look at the introduction of the Neolithic way of life in Southeastern Europe. Changing paradigms of the expansion of the Neolithic way of life
}

\author{
Mehmet Özdoğan \\ Istanbul University, İstanbul, TR \\ c.mozdo@gmail.com
}

\begin{abstract}
Questioning when, how and even why the Neolithic way of life appeared in Europe has been one of the most debated problems of European prehistory, leading to the formulation of various explanatory models, each providing evidence to support its point of view, but without convincing others. Conventional standpoints, one-tract thinking and considering the emergence of the Neolithic way of life as a short-term event have hampered consensus, bringing discussions almost to a deadlock. Recent evidence has made it clear that the Neolithisation process in Europe was a multifarious event that went on for more than a millennium; thus, all previous hypotheses were correct with regard to their specific cases. Analytic or synthetic explicative models such as migration, colonisation, segregated infiltration, the transfer of commodities and of know-how, acculturation, assimilation, and maritime expansion that are seemingly mutually contradictory actually took place simultaneously as distinct modalities.
\end{abstract}

IZVLEČEK - Vprašanja kot so kdaj, kako in celo zakaj se je neolitski način življenja pojavil v Evropi predstavljajo temelje razprav o Evropski prazgodovini, ki so vodila $k$ oblikovanju različnih razlagalnih modelov, ki so vsak zase podprti z dokazi, ki jih prinašajo, a so hkrati nezdružljivi z drugimi modeli. Tradicionalna stališča, enoumno razmišljanje) in razumevanja pojava neolitskega načina življenja kot kratkočasnega dogodka ovirajo konsenz ter so pripeljali razpravo skoraj na mrtvo točko. Nedavni dokazi kažejo, da je bil proces neolitizacije v Evropi raznolik, več kot tisočletje trajajoč pojav, tako da so prejšnje hipoteze, vsaka zase, pravilne. Analitski ali sintetski razlagalni modeli kot so migracija, kolonizacija, segregirana infiltracija, izmenjava izdelkov in znanja, akulturacija, asimilacija in pomorska ekspanzija, ki so si navidezno medsebojno nasprotujoči, so se dejansko lahko odvijali sočasno kot različne modalitete.

KEY WORDS - Neolithic dispersal; Neolithic package; segregated migration; Marmara region; Anatolia

\section{Prelude to the problem}

Discussions on when and how the Neolithic way of life was introduced to Europe have a century-long history, a trajectory of thinking and arguments swaying from one extreme to the other (Budja 1993; 2004; Özdoğan 1995; Sherratt 1997; Tringham 2000). Initially, almost up to the late 1970s, there was not much to discuss; endemic diffusion - almost in colonisation mode - was considered the indubitable explanation for the emergence of the Neolithic way of life in regions outside the Near East; thus, debates mostly targeted its subsequent stages. Here, it should be noted that in the decades following World
War II, there was a growing tendency in social sciences to unscramble conventional approaches; as is often the case, it took some time for the quest to break away from the traditional frameworks to influence European prehistoric archaeologists (Barford 2002; Bentley 2006). It mainly took the form of a total denial of cultural diffusion; thus, expansionist models propagating the Near East or Anatolia as the origin of European Neolithic were met with considerable reaction, at the same time triggering a fierce debate between defenders of conventional models and defenders of the autonomy of the Eu- 
ropean Neolithic. Inevitably, through the final quarter of the last century, the question 'How?' became the central focus of discussions; a number of controversial models were formulated and debated. For some years there has been a shift back to what might be termed 'neo-diffusionism'; nevertheless, it is far removed from the over-simplistic narratives of previous decades.

At the time when we presented a paper to $\mathrm{Docu}$ menta Prehistorica almost 20 years ago (Özdoğan 1995), very little was known from the Northwestern parts of Turkey on the early stages of Neolithisation, so most of what we had noted was based on intuitions rather than on concrete data. In that paper, we stressed the fact that biases in the quest for the beginning of Neolithic life in Europe had their roots in the unbalanced distribution of evidence between Southeastern Europe and Anatolia: while the former was known through hundreds of excavations, the work on Anatolia was minimal. Nevertheless, in spite of the paucity of evidence, certain indicators hinted at connections between the Neolithic assemblages of the Balkans and Central Anatolia, making it possible to surmise an endemic movement out of the Anatolian Plateau in the direction of Southeastern Europe. However, at that time, no data were available from the interim zone, i.e. the region around the Sea of Marmara, so we left our view as a suggestion. Rather paradoxically, over-documentation or the excessive number of studies in the Balkans had paved the way for other biases, the overall picture being blurred by being lost in details. Throughout Southeastern Europe there has been an apparent over-emphasis of the stylistic features of pottery assemblages, overriding other components of the material evidence, with cultures occasionally being defined by scrupulous categorisations of decorative elements - in a way, 'Balkanising' cultures that are more or less similar to the level of the smallest geographic unit. Nevertheless, with the inflow of new evidence from the Western and Northwestern parts of Turkey, it became possible to elaborate the picture we had drawn 20 years ago. Although there are still considerable gaps in our knowledge and various pitfalls in assessing the evidence, it is now at least plausible to develop a comprehensible view with a supra-regional perspective based on subtle evidence. In this respect, one more point needs to be defined: the archaeologies in Southeastern Europe and in Anatolia-Near East developed as distinct fields of specialisation, with little or no contact between them for decades, thus hampering the flow of knowledge, modalities and terminologies as well; the significant dif- ference between the Anatolian and Balkan archaeologies in, for example, what is meant by terms such as 'culture' or 'material assemblage' had considerable implications for developing a mutual understanding between the two sides (Özdoğan 2004). In the tradition of Anatolian archaeology, as in most Near Eastern archaeology, proxies other then stylistic variants are taken into consideration to define cultures in time and in space. What is denominated as the 'Halaf' culture best exemplifies the conceptual approach of Near Eastern archaeology. Halaf culture extends from western Iran to Cilicia, in an area comparable in size to the Balkan Peninsula, with numerous stylistic variants that are much more apparent then those between Sesklo - Starčevo - Kremikovci Gradesnitsa - Karanovo I - Körös and Çris, although it is still called Halaf Culture.

One significant novelty of the last two decades has been the shift in research priorities, both in Anatolia and in the Balkans, which regretfully has not helped to answer the ultimate questions as much as it could have. While Neolithic sites began to be excavated in previously unexplored regions of Western Anatolia, the number of Neolithic excavations in the Balkans, where the focus of interest was diverted to the later periods of the Neolithic, declined sharply. Having large-scale exposures is one of the principle excavation strategies in Turkey, whereas most of the recent work in Southeastern Europe, with the exception of rescue operations, are carried out as restricted soundings and even as core-drillings. Evidently, this also makes it more difficult to make secure comparisons between the two regions.

Archaeology in Anatolia developed from 'Mesopotamia-centric' roots, almost totally overlooking what had taken place in the west, or more specifically, in the prehistory of the Balkans. Although this has been somewhat ameliorated in the last decade or so, the aftermath of Mesopotamia-centric thinking still prevails (Özdoğan 1997). Thus, collating the archaeological evidence of Anatolia with the Balkans has its particular problems, which are apparent even in border regions that are separated only by present-day political borders. In spite of all the drawbacks, some progress has been made to improve the development of mutual understanding between the archaeologies of Anatolia and the Balkans by at least being aware of what is happening on the other side.

Within the framework of this paper, it is not possible to present even a conspectus on the newly emerging picture; instead, we shall be concerned with new 
ways of looking at this century-old problem from the standpoint of changing paradigms. The term 'Neolithic package' seems to have taken a central place in current debates on the origin and dispersal of the Neolithic way of life; however, it is also clear that what is implied by the term 'Neolithic package' is not always the same. Accordingly, for the sake of clarity, we first have considered looking into the coverage and implications of this term.

\section{The 'Neolithic package'}

The concept of Neolithic grew with what had been defined as the 'primaries', consisting of constructed spaces indicating permanent habitation, domestic animals, cultivated cereals and legumes indicating food production, pottery vessels indicating storage and cooking, ground stone objects indicating food processing, celts indicating a new technology of finishing stone tools by polishing. Until recently, the presence of 'primaries' sufficed to denominate a site as Neolithic, as the Neolithic period was viewed as a period of simple farming communities striving to survive and gain dominance over their habitats. Thus, detecting the absence or presence of the primaries was, more or less, the prime objective of research for a long time. While most components of the package such as architecture, pottery and ground stone are easy to detect, determining agricultural practices and domestication of animals necessitated work by special experts; thus working on floral and faunal remains soon became the main objective of Neolithic excavations. Through the meticulous work of natural scientists, the much needed data leading to summarizing the stages towards food production became available; however, at the same time, the Neolithic came to be conceptualised in terms of subsistence, overlooking the structure of cultural and social entities. Moreover, the prominence given to subsistence patterns has hampered the search for answers to other questions, including 'origins' or 'identity', that are essential to understanding the modalities of Neolithic dispersal.

The recent picture of the Neolithic of the Near East is far more sophisticated and multifarious than what could have been imagined in the previous decades, necessitating other sets of questions that would enable us to follow origins, sequences of developments, trajectories of dispersal, spheres of interaction etc. It also became evident that in the early, pristine stages of Neolithisation, what was being consumed as food was not as important for Neolithic communities as we have hypothesised. It is apparent that Neoli- thic communities did not identify themselves with how they procured food, while some remained hunters for long periods, others were utilising various cereals or legumes, or managing sheep, goat or cattle. Regardless of their subsistence pattern, they interacted, sharing knowledge, which clearly indicates that their socio-cultural identity was the prime marker that differentiated them from other groups. Thus, the course of our thinking on Neolithic communities fixed on the efficiency of food production has to be revised to enable new paradigms to be developed for holistic approaches (Özdoğan 2002).

With the increase in our knowledge of the Neolithic Period defining what is implied by the term, the Neolithic became far more difficult than before; now, the definition varies according to the types of question being asked. However, any hypothesis based on conventional 'primary' elements would fail to answer even the simplest questions. Although the term 'Neolithic package' has emerged to mark the multifarious outlines of Neolithic cultures, considering it as a single, homogenous package is as misleading as the earlier assumptions. The Neolithic package has to be defined and specified both in time and space as distinct packages.

Following this idea, we have devised a tentative list of proxies to specify and diagnose Neolithic packages and tested them to construe various clusters, spheres of interaction, and trajectories of dispersal. As our approach and methodology have been described elsewhere in detail (Özdogan 2010b; 2011a), this paper is limited to presenting some of the basic issues that are relevant to the discussions here. As the first step, we began by defining 52 components of the Neolithic assemblages that we considered as indicative of tracing cultural clusters (Özdoğan 2010b.Tables). These ranged from settlement layout to architectural designs to symbolic or prestige objects to utilitarian tools that reflected either certain technologies or traditions. During the later stages of our work, we extended the list to 94 by adding new components. The results are by no means conclusive, and are apt to be expanded and elaborated by time; however, at least they provide a subtle basis for investigating certain problems. The list should be considered as a database intended to cover various Early Neolithic assemblages in an extensive geography, as a guide to what to look for. Methodologically, our approach is basically the same as what was devised to trace the distribution patterns of the 'crop package' of founder crops (Colledge, Conolly 2007). 
The next stage of our work has been to define spatial and chronological zones that would be the final basis for sorting the list, enabling us to trace the distribution patterns of the components of the Neolithic package. With a supra-regional view, trying to avoid local variations, we defined seven geographic zones, each of which has more or less similar traits during the initial stage of Neolithisation (Özdoğan 2012.Fig. 1); the annotated geographic units used to plot entities of the Neolithic package will be described briefly.

\section{Designating geographic zones}

Seven geographic zones that could potentially contribute to tracing the spatial distribution patterns of the Neolithic package have been defined (Fig. 1); these are:

Zone A: The main core area of Neolithisation, covering the Central Anatolian plateau, the Levant, northern Syro-Mesopotamia, Southeastern Turkey and Western Iran. The Neolithic way of life emerged within this zone as early as the $11^{\text {th }}$ millennium calBC and continued to develop for some 3000 years without expanding its boundaries or having a detectable impact on other regions. The vast territory that has been denominated as the core or the formative zone of primary Neolithisation is not a uniform entity, but consists of at least three sub-divisions: the Central Anatolian plateau, Southern Levant, and the region conveniently named Greater Mesopotamia; each featured its own particular settlement pattern, architectural design, material assemblage, burial customs, symbolic indicators and technologies. However, in spite of the apparent differences, there was still an intensive interaction and, more significantly, sharing of knowledge throughout the entire area of Zone A, regardless of the diversity of their cultural systems.

Zone B: The immediate periphery of Zone A, where the components of the Neolithic package began to appear by the turn of the $8^{\text {th }}$ to the $7^{\text {th }}$ millennium $\mathrm{BC}$, although rather sporadically. The boundaries of this zone are not well defined, seemingly changing through time. The Western parts of the Anatolian peninsula and, possibly, the littoral areas of the Aegean comprise Zone B. Most of the terrain covered by Zone B comprises small intermountain plains, some - like those in the Lakes district - occupied by lakes and alluvial valleys extending along tectonic fault-lines. The picture along the littoral areas of the Mediterranean coast is not that clear. The maritime route following the coastline of the Neolithic era seems to have been as effective as that of the land route (Özdoğan 2011b).

The appearance of Neolithic elements in the region at the initial stage seems to have been rather sporadic and random. The initial stage seems to continue until about 6500-6400 BC, being followed by more intensive and organised waves of intrusion, each following different trajectories and bringing together distinct Neolithic packages, with the final and more intensive wave dating to a time around $5600 \mathrm{BC}$. Maritime routes, whether following the coast or not, must have been as important as those of the landroutes through Anatolia in the expansion of Neolithic communities (Perlès 2005; Özdoğan 2011b). It is also of interest to note that the communities established in the new areas mentally and physically were not totally detached from their land of origin. Through the initial stages of Neolithisation up to the end of the Early Chalcolithic Period, communities living in these areas were evidently aware of the changes taking place in the core area. David Anthony (1997) calls sustained relations with the old homeland by constant back-and-forth movements between the core and periphery as "chain migration" ( $A n$ thony 1997.24); the same generalisation holds for Zones C and D.

Zone C: This covers the north-south oriented corridor in inner-west Anatolia and the eastern parts of the Sea of Marmara. At its southern end, Zone C touches the Lakes District of Zone B. It seems highly probable that the initial wave out of Central Anatolia, after reaching the Lakes District, diverged into two branches, one going westward into Zone B along the valley of the Menderes River and the other northwards along the Sakarya River, reaching eastern Marmara by $6500-6400 \mathrm{BC}$, taking with them the Neolithic package characterised by the so-called 'monochrome' assemblage, which in time will emerge as the Fikirtepe group. In an overview, this process of Neolithisation differs from the others. Firstly, the coastal regions of eastern Marmara were densely occupied by the Mesolithic communities known as the Ağaçlı group. There, as evidenced at sites such as Yenikap1, Fikirtepe and Pendik, both groups peacefully merge, developing a coastal variant of the Fikirtepe culture that differs from those of inland sites such as Demirci Höyük, Barçın and Kanlıtaş Höyük. The migration of Neolithic farmers after integrating with the local communities ends in the region around the Istanbul area, with no attempt to move further into Thrace. Secondly, this zone was totally avoided by the second and more massive movement 


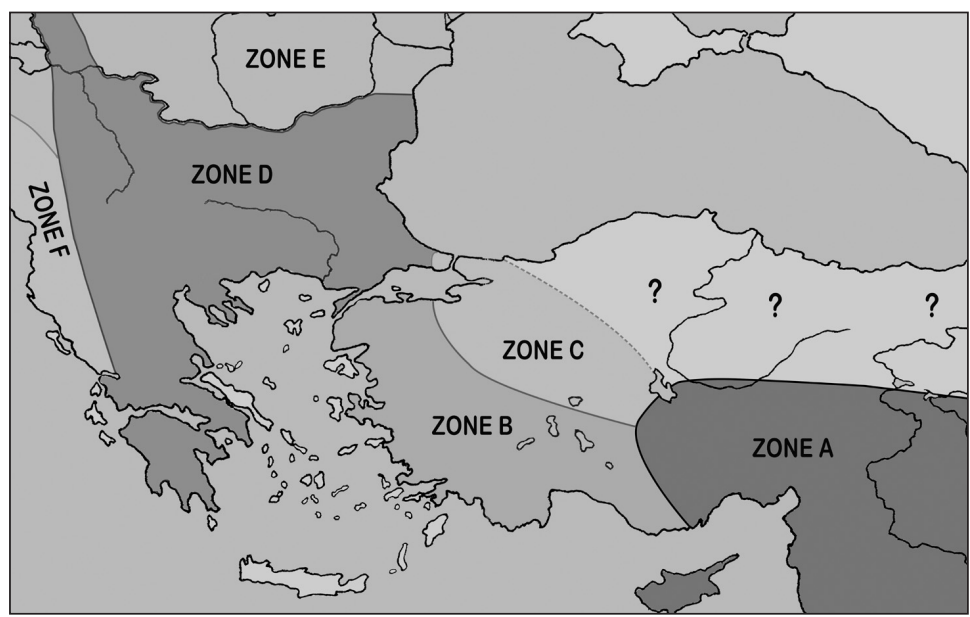

Fig. 1. Geographic Zones designed to follow Neolithic packages.

throughout the vast geographical area extending from the Aegean to the $\mathrm{Da}$ nube indicates that the occupation by Neolithic migrants was very rapid.

In parts of Southeastern Europe where there was a strong presence of Mesolithic communities, the process of Neolithisation took place in different modalities that varied from region to region, either as gradual acculturation or adaptation, as in the Iron Gates and Western Balkans (Bonsall 2007; Boric 1999; 2011) or as in the case of Eastern Marmara, the peaceful merging of two communities. It is of inte-

which brought with it the Neolithic package characterised by the red-slipped pottery assemblage. We were rather startled by the different compositions of the Neolithic packages of Yenikapı-Fikirtepe-Yarımburgaz group and that of Aşağ1 Pınar in Eastern Thrace, only $100 \mathrm{~km}$ away; this will be further detailed below

Zone D: This covers most of the Aegean and the Balkans, with the exception of the Adriatic littoral. Evidently, this vast territory could also have been broken into several smaller units, the most apparent being the southern parts of the Greek peninsula that feature rather distinct from most of the Balkans. As noted for Zone $\mathrm{B}$, the maritime routes seem to have been more effective in bringing in Neolithic elements. Perlès (2005) has explicitly noted that there must have been some direct connections between the northern Levant and mainland Greece that bypassed the Anatolian peninsula.

The initial wave of Neolithic expansion reached some parts of Zone D by 6500- $6400 \mathrm{BC}$, though extremely sparsely and even indistinctly in most areas. As in Zones $\mathrm{B}$ and $\mathrm{C}$, this initial stage is characterised by the Neolithic package of monochrome pottery. Although infiltration into the region seems to have been sustained for some centuries, at around 6100$5900 \mathrm{BC}$ there is a considerably massive and organised migration, as evidenced by the rapid foundation of hundreds of new settlement sites in almost every alluvial plain and valley throughout Greece and the Balkans, bringing with them the package of the red-slipped horizon. Throughout the region, the material assemblages present an apparent uniformity, and almost every component of the Neolithic package appears in a fully developed stage. The sudden appearance of similar or even identical elements rest to note that Zone $\mathrm{D}$, after following the trends in Zones A and B in the initial stages, later became detached to develop as a new core for the Neolithisation of areas further in Central Europe.

Zone E: This covers those parts of Central and Western Europe where the Linear Band Ceramic assemblages appear as a uniform entity. In spite of the discrepancy regarding its origins, during its later stages it developed as an independent identity, being totally detached from events that took place at the core area of primary Neolithisation (Bánffy, Sümegi 2011; Oross, Bánffy 2009).

Zone F: This is the Central and Western Mediterranean, the region of so-called Impresso and of Cardium-Impresso groups. This zone can also be broken into numerous regional variants, partly due to distinct environmental features, partly because of the strong presence of Mesolithic groups preceding the arrival of Neolithic elements. Although the appearance of Neolithic package happened as early as the mid-6th millennium $\mathrm{BC}$, indicating the effective implementation of maritime connections through out the Mediterranean basin, it is also clear that the dispersal of Neolithic elements was not due to endemic movements, but resulted from the transfer of commodities and/or know-how.

Zone G: This covers the northeastern parts of Turkey and most of Caucasia, where the appearance of Neolithic elements appear as late as the $6^{\text {th }}$ millennium $\mathrm{BC}$, seemingly not due to an endemic movement, but to the transfer of commodities and knowhow.

The geographic zones noted above, with the exception of Zone A, should not be considered as definite 
entities, but more as starting points for testing working hypotheses. Firstly, none of them has clear boundaries; moreover, their areas and position in the process of Neolithisation changes through time. Likewise, any of them could be further segregated into different units or merged with each other. Nevertheless, the template suggested here enables us to trace the distribution patterns of various Neolithic packages and demonstrate regions of origin. Even a preliminary assessment has revealed that the spread of Neolithic culture in Zones B, C and D was due to multiple waves of very rapid endemic movements covering large territories relatively quickly. We are aware that what has been noted above covers a wide and diversified geographical area, inevitably leading to questions about the pace at which communities and or commodities could move.

\section{Pace of Neolithic dispersal}

It has often been argued that the movement of communities that lack pack animals must be very slow, so seeking analogies to present-day nomadic tribes would be erroneous. Accordingly, various models have been suggested for the spread of Neolithic communities, such as leap-frog and wave of advance; almost all of them consider a very slow pace of expansion, almost in the range of one kilometre per year. In calculating the pace of migration, demographic built-up, the time needed for demographic pressure to built up to a level that would trigger people to move in search of new areas to settle has been one of the main concerns. Most of these models have been explicitly described and discussed in a number of works, so we refrain even from presenting a review of these (Bellwood, Renfrew 2002; BocquetAppel et al. 2009; Harris 2003; Pinhasi 2003; Price 2000; Richards 2003; Zvelebil 2002; 2005). Before going into problems related to demography, which we deal with below, some facts concerning the pace of the movements need to be discussed.

In estimating the pace of Neolithic expansion, the available radiometric dates are not of much help in specifying the time of the initial stages of the movement because, firstly, the margins of absolute dates are wide, and secondly, those from the basal layers of occupation are very few in number and rather random. Nevertheless, they help to place cultural assemblages in the main stages of

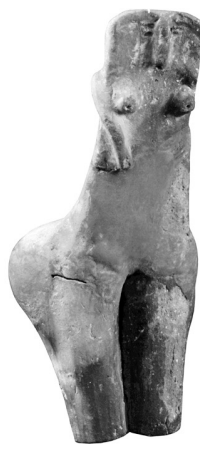
insula.
Neolithic dispersal, such as the 7200-6400, 64005900, 5900-5600 BC general slots.

Accordingly, until more precise absolute dates are available, other agents have to be looked at to view the pace of dispersal. In this respect, the level of uniformity and similarities in the stylistic details of material assemblages within Zones $\mathrm{B}, \mathrm{C}$ and $\mathrm{D}$ is remarkable. For example, what we have been recovering in Layer 7 of Aşağ 1 Pinar in Eastern Thrace is identical to contemporary material not only from Bulgaria, but also Macedonia and the Danubian basin, as if the same craftsmen had made them (Fig. 2). In our view, this could only have occurred if the expansion was very rapid, giving no time for stylistic changes or the introduction of new components to the assemblage. So the problem is: how rapid can the movement of Neolithic communities that are in search of new areas of habitation have been? Although - as mentioned above - estimates deduced from the pace of migration of present-day nomadic groups is considered to be misleading; it should also be considered that, even if they possess pack animals, the speed of their movement depends on the distance a flock of sheep or goats can walk in a day. In their annual migration from wintering grounds to summer pastures, modern sheep-herding Turcoman tribes move an average of 8 to $15 \mathrm{~km}$ per day, and within two to three weeks they travel 150 to $250 \mathrm{~km}$ to cross over the Taurus Mountains. In alluvial plains or steppes, the distance covered in a day can be even greater (Bates 1973; Danısmaz 2012; Hütteroth 1959). Even if this is considered an exaggerated estimate for movement through hostile environments, from Aşağı Pınar in Eastern Thrace to the basin of the Danube, which is only $250 \mathrm{~km}$ as the crow flies, can easily be covered during a season. Accordingly, once people have a motive to migrate, the distances that we conceptualise as unfeasible are actually achievable within reasonable periods. We
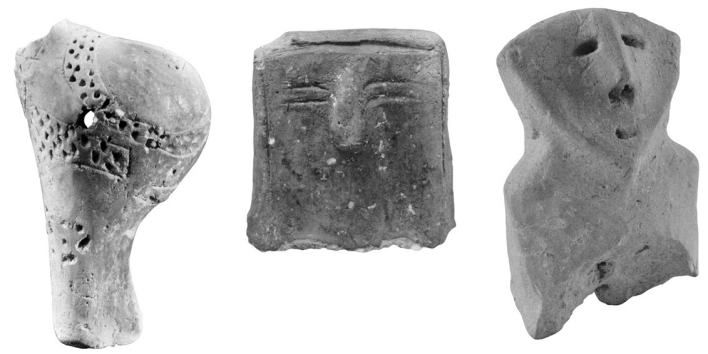

Fig. 2. Clay figurines of Aşağı Pınar 7; finds identical to these are extensively distributed throughout almost the entire Balkan Pen- 
thus surmise that the regions of the Karanovo I and related groups, for example, could be occupied by immigrating farmers within a year or two, providing their numbers were sufficient to fill this area. This leads to the question of how to differentiate between settlements founded by immigrant groups and 1ocal communities that were Neolithicised either by acculturation or adaptation.

\section{Identifying endemic movements: 'village life' as an indicator}

To what extent migrant farmers were the actual founders of the Early Neolithic sites of Southeastern Europe and how these can be differentiated from those due to cultural interaction is a critical question in understanding the process of Neolithisation; no matter how simple it looks, the answer is not easy. The presence or absence of certain components of the Neolithic package and, in particular, types of artefacts, are not dependable criteria for answering this question, as commodities and technologies can easily be transferred and adopted. Likewise, certain utilitarian or prestige items that require skill and experienced know-how to manufacture could have been distributed by wandering craftsmen; thus, by following this line of thought, a consensus is difficult to reach. On the other hand, 'village life' is a more dependable criterion if what is implied by the term can be properly defined.

Settlements in the core area of primary Neolithisation, Zone A, had become 'villages' as early as the beginning of the Pre-Pottery Neolithic stage, developing life-styles markedly different from those of 'other' communities. Alhough discerning criteria for village life is not easy, regardless of the artefactual assemblages, even by looking to the plan of a settlement anywhere in Zone A, be it in the Southern Levant or in Central Anatolia, they clearly reveal a picture of a village in the true sense of the term, where the presence of complex social order is apparent (Fig. 3). Thus, Neolithic farmers on the move had behind them the social memory of a tradition established several millennia previously, which can be clearly viewed in the newly founded settlements in Zones B, C and D. It seems evident that the immigrant groups could not give up the modalities of life to which they were accustomed when settling down. The social modalities of village life are not easy to adapt for an outsider. It requires long experience and a tradition to be comfortable with; thus, it cannot be imitated in a short period. It is for this reason that we included way of village life as one of the major components on our list. Even the earliest settlements in Zones B, $\mathrm{C}$ and in nuclear sectors of $\mathrm{D}$ are villages in the sense of Anatolian and/or Near Eastern ones, regardless of their size, layout or construction techniques. However, none of those on the fringes of Zone $\mathrm{D}$, and almost none that are in Zone $\mathrm{F}$ are habitation sites in the tradition of the eastern Neolithic. Accordingly, as a working hypothesis, the type of habitation is apt to be an indicator in defining the area covered by endemic movements.

Social meaning attached to the living space is consequential to the development of village life; it is bound tightly to the concept of a 'new way of life' and is another criteria with which to identify settlements established by immigrant farmers. In the Zone A tradition, buildings are not mere shelters, but homes, structures ascribed to new values; likewise, compared with conventional dwellings, Neolithic houses are multifunctional, closely reflecting modalities of the new way of life (Özdogan 2010a; Watkins 1990; 1996; 2012). The transition from simple huts to houses, the consolidation of the living space to comply with the expectations of the Neolithic way of life, took place in Zone A at a very early stage. Even during the Pre-Pottery Neolithic A period, when

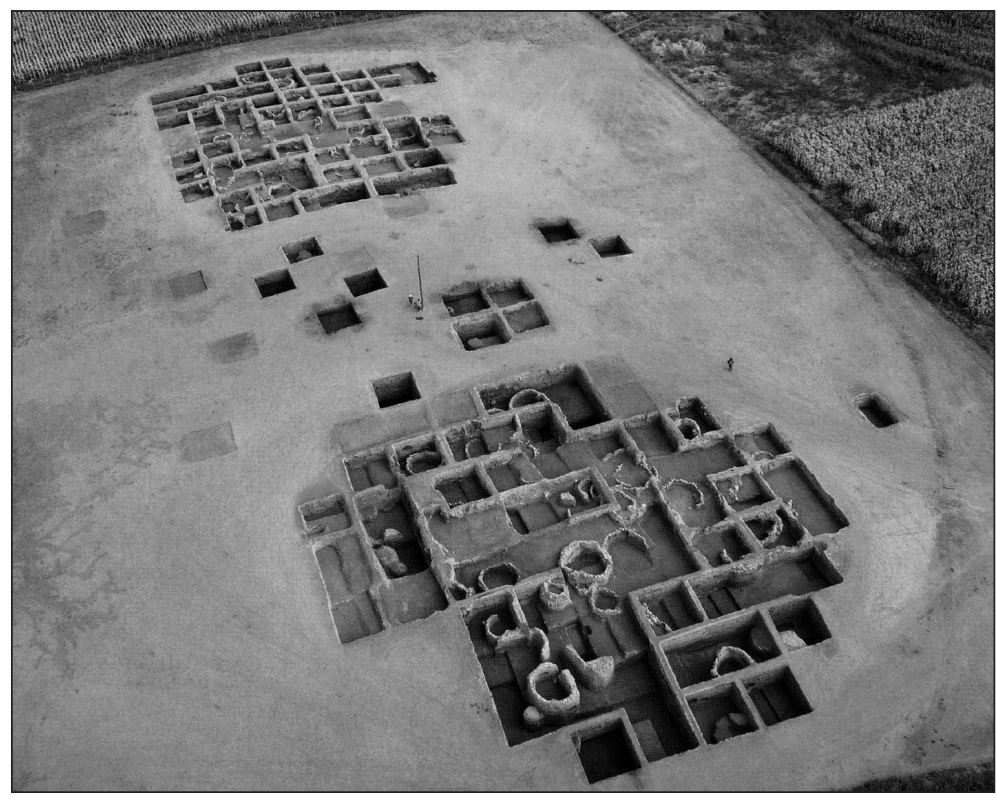

Fig. 3. Aerial view of Körtiktepe, a Pre-Pottery Neolithic A site in Southeastern Turkey (from Özkaya et al. 2013). 
the building plans were circular, they were already houses, not simple huts (Figs. 3-4). The development of building techniques that required structural innovations was a long process; through trial and error; stable rectangular-plan buildings had already appeared in Zone A by the transition from Pre-Pottery Neolithic A to B (Özdoğan 2010a). Accordingly, by the last quarter of the $9^{\text {th }}$ millennium BC, buildings throughout Zone A were rectangular in plan and multifunctional, representing well-developed structural practices designed to leave open spaces in between for other activities. On the other hand, the dwellings of contemporary Mesolithic communities were exclusively light, hut-like structures, round or oval in plan. Immigrant farmers coming from Central Anatolia were accustomed to solid houses. After entering the temperate forest zone, possibly in Zone $\mathrm{B}$, they began practicing with wood as a building material and rather quickly became acquainted with using wooden posts and timber to build rectangular, solid and multifunctional houses. Although some round plan buildings occur at newly established coastal sites such as Hoca Çeşme or Ege Gübre, they are also solid structures with stone foundations incomparable to the hut-like dwellings as in the peripheral areas of Zone D.

Accordingly, we also consider the presence of huts or homes as an indicator to set settlements founded by immigrants apart from others. In this respect, the difference between the settlements of coastal and inland sites of the Fikirtepe culture presents a fine example (Özdoğan 2013a). Sites located distant from the coastal areas without a Mesolithic substratum are villages in the true sense of Neolithic settlements of the core area. However, at coastal sites where local Mesolithic groups merged to live together with the newcomers, the picture is notably different. Recent excavations at Pendik revealed a rectangular mud-slab building (Fig. 5) in the same layer, with numerous round or ovoid wattle-and-daub hut-like dwellings (Kizıltan 2013). Likewise, Starcevo, Körös and Cris settlements in the marginal areas of Zone D also differ from those in the central sections as they consist of huts, and the settlement habitation areas lack the indicators of 'village life'. Accordingly, it is possible to surmise that the endemic movement covered only parts of the Balkan Peninsula, mainly northern Greece, Eastern Thrace, Bulgaria, Macedonia and only parts of Serbia.

\section{Demography}

In seeking modalities that might have triggered communities to leave their homeland, increases in population that exceeded the carrying capacity of the terrain have always been on the agenda as being among the most probable options. It has been generally argued that deterritorialisation of habitat either by intensive consumption or climatic fluctuations, or by the overpopulation due to the optimal living conditions brought by the Neolithic way of life, were the main agents leading to the momentum to migrate (Bocquet-Appel, Bar-Yosef 2008; Bar-Yosef 2009; Clare et al. 2008; Goring-Morris, Belfer-Cohen 2008; Rollefson, Köhler-Rollefson 1989; Weninger et al. 2009; Sherratt 2004). Some sort of social unrest or turbulence has also been considered as a reason for massive movements from the core area to other regions (Clare 2010; Özdoğan 2013a). Although what may have led populations to migrate is beyond the

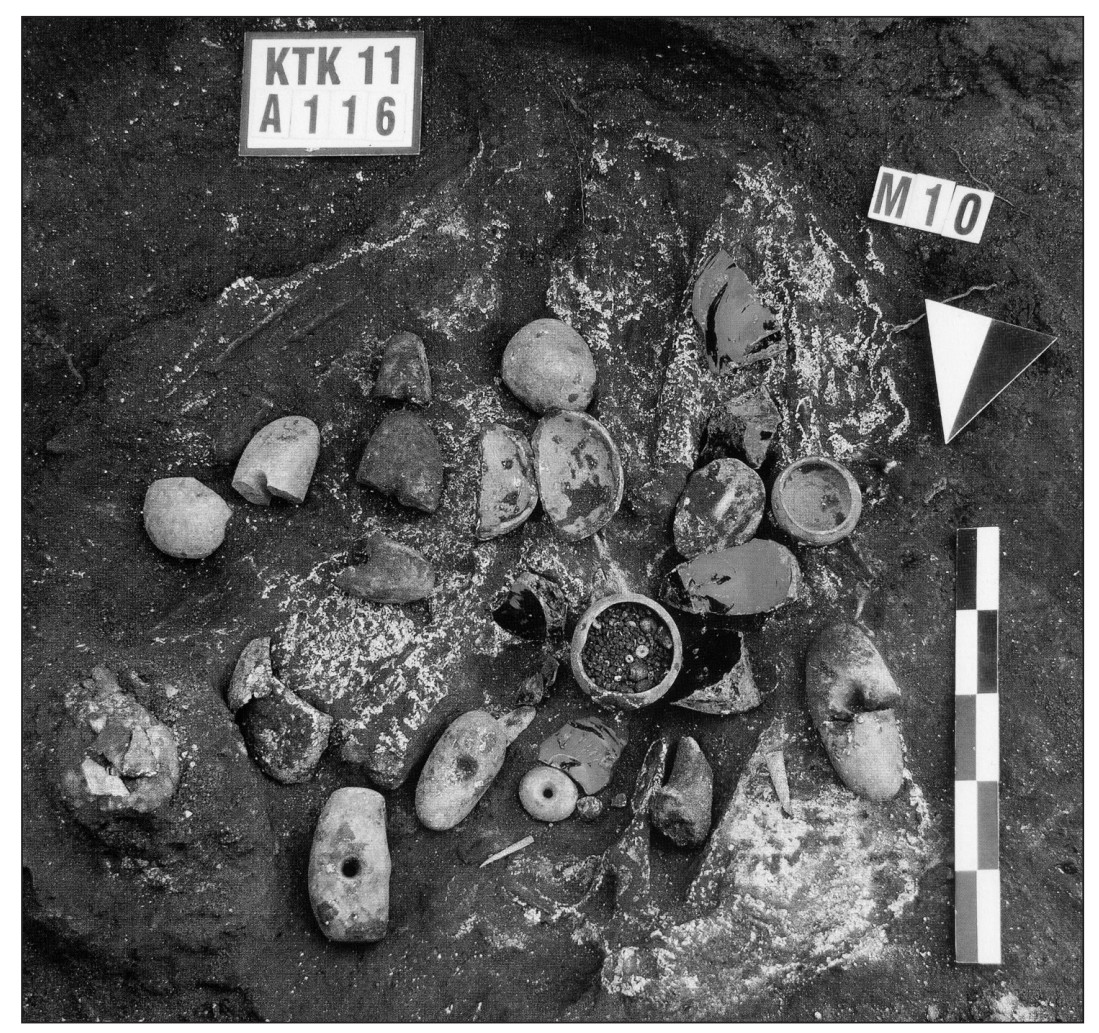

Fig. 4. Burial gifts of a sub-floor burial from a round building of the PrePottery Neolithic A at Körtiktepe (from Özkaya et al. 2013). 
concern of this paper, there is clear evidence of population displacements both in the southern Levant and in Southeastern Anatolia, some sites being abandoned, others diminishing in size, eventually leading to what has been termed the 'Neolithic Collapse' by the last quarter of the $8^{\text {th }}$ millennium $\mathrm{BC}$; this is also a period when previously unattested elements of the Levantine and Southeastern Anatolian Neolithic cultures begin appearing on the Central Plateau (Özdogan 2013a; 2014). It is thus possible to surmise that some groups, mainly farmers and herders with the now fully domesticated animals, had left the eastern parts of Zone A, moved into Central Anatolia and merged with the local communities, with which they had long-standing connections. It is of interest that no component of the dominant clerical system of the east was transferred to the west; seemingly the movement was by ordinary people, while the ruling elite or the clergy remained, which is highly suggestive of some sort of social turmoil (Özdogan 2008. 141). It also seems plausible that after entering Central Anatolia, some people kept moving west, firstly as stray bands and then in a massive and more organized fashion. However, whether prior to the mass movement of around $6000 \mathrm{BC}$, the level of population growth had reached a level that would cover Zone $\mathrm{D}$ is a question that still needs to be answered.

Related to the demography question, it should also be taken into account that the westward expansion of Neolithic farmers was not a singular event, but took place in multiple installments extending through a millennium, each wave bringing together certain components of the Neolithic package and having its distinct trajectory. The evidence from Neolithic excavations in Western Turkey indicates that in deciding locations to settle, migrating groups omitted places that had been occupied by the previous newcomers. Accordingly, the content of the Neolithic package differs not only in time, but also locality. For example, in a relatively small area around İmir, five Neolithic sites have recently been excavated, Çukuriçi, Latmos Beşparmak, Ege Gübre, Ulucak and Yesilova, and there are apparent differences among the material assemblages of layers that are even contemporaneous.

\section{A case study: comparing the Neolithic packages of two neighboring regions}

With the onset of numerous Neolithic excavations now mounting to 13 altogether, the region around the Sea of Marmara provides the means to exemplify some of the issues mentioned in this paper. As the details of the sites with extensive bibliography have been published elsewhere, they will not be repeated here (Özdoğan et al. 2013). Among them, Gürpınar, Çoşkuntepe, Uğurlu and Hoca Çeşme, are located in the western sector of the region, almost along the coastal strip of the Aegean; Yarımburgaz, Yenikapı, Fikirtepe, Pendik, Ilıpınar, Menteşe, Barçın in the eastern sector; and Aktopraklık and Aşağ $\mathrm{P}_{1-}$ nar in the interim zones by geographic location (Fig. 6). Among these sites, Fikirtepe was the first to be excavated (1952-54) followed by Pendik, Yarımburgaz, all located in the eastern part of the region. When we began working on the Neolithic assemblages of these sites in the 1980s, even at the initial stage of our assessment, it was possible to detect numerous finds that are similar to the Neolithic assemblages of both the Lakes District in Turkey and the so-called Karanovo horizon in the Balkans. Similarities in tool types such as the bone spoons, belthooks etc. were too specific to be explained by parallel developments. This led us to conclude that the Fikirtepe culture of Eastern Marmara derived from the Neolithic sub-stratum of the Lakes District, at that time known mainly from Hacilar, Kuruçay, Erbaba and Süberde, and that it was ancestral to the

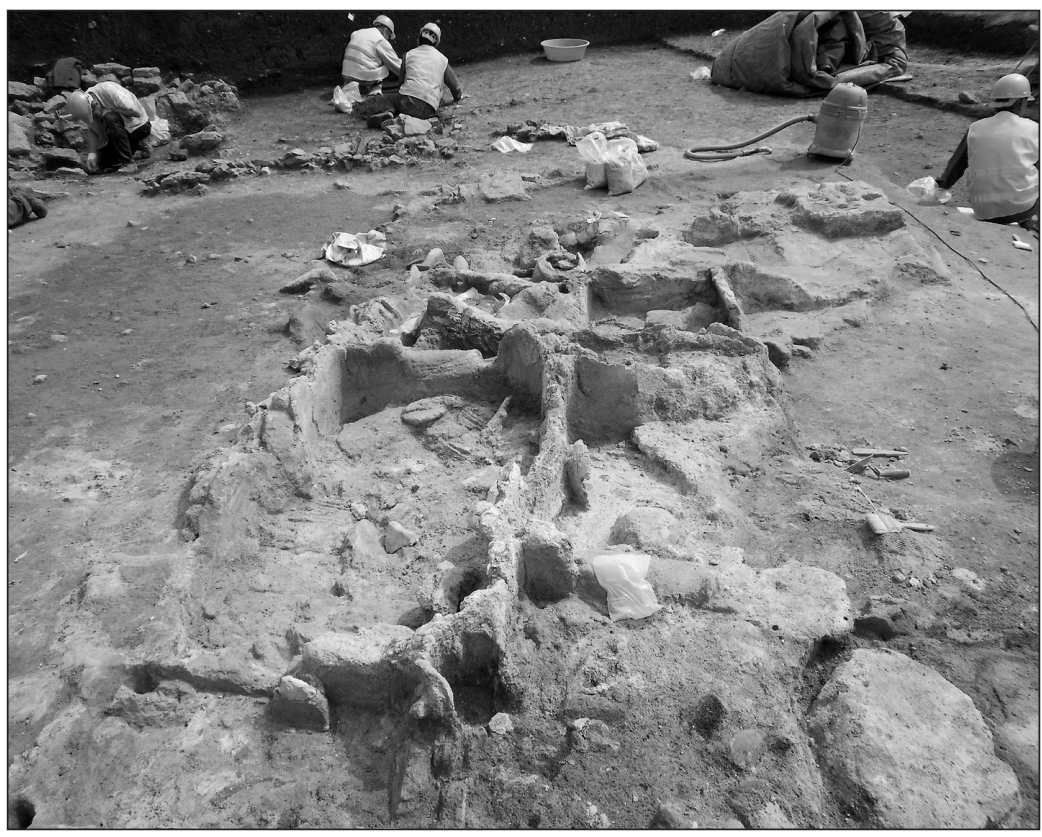

Fig. 5. The rectangular mud-slab building at Pendik excavated in 2013 (courtesy of the Istanbul Archaeological Museums). 
Neolithic cultures of Bulgaria (Özdoğan 1995; 1997). With that view in mind, through our early work in Thrace, we tried to detect elements specific to the Fikirtepe culture in Thrace and were somewhat misled by the presence of certain dark-coloured wares. The absence of certain elements of the Karanovo assemblage at Fikirtepe, such as red-slipped painted wares, tubular lugs, pedestalled bases was rather startling, but we considered that the second wave that brought red-slipped painted pottery to the Balkans had bypassed Eastern Marmara. Excavations at Hoca Çeşme were in a way an indicator of the difference in the Neolithic assemblages between the eastern and western parts of the Marmara region, but not conclusive, as the excavations were on a rather limited scale. Excavations at Aşağ 1 Pınar provided ample evidence to draw a clear picture; firstly, because there was a clear uninterrupted cultural deposition covering the entire sequence of the Early Neolithic period and the large extent of the exposures; it is now evident that the basal layers of Aşağı Pınar, layer 8, pre-dates Karanovo I and is contemporary with early Fikirtepe, while Aşağ 1 Pınar 7 is contemporary with Karanovo I and Yarımburgaz 4 (Özdoğan 2013b). In an overview, neither Aşağı Pınar 7 or 8 have elements typical of Fikirtepe-Yarımburgaz group with the exception of elements that are common to all of Zone A and $\mathrm{B}$; on the other hand, the basal layers of Aşağ1 Pinar have the characteristic features of pre-Karanovo and Karanovo I cultures, also sharing the same assemblages as sites such as Hoca Çeşme, Uğurlu etc. in western Marmara. Some of the most characteristic features will be discussed in some detail below.

One of the most striking differences between the east and west Marmara assemblages is apparent in the lithic industries (Gatsov 2001; 2003); the sites of the Fikirtepe culture, both the coastal sites such as Yenikapı, Fikirtepe, Pendik and the inland sites such as Ilıpinar, Barçın, Menteşe, Aktopraklı have a very distinctive micro-blade industry, notably featured by pressure flaking and bullet cores (Fig. 7). Round curricular scrapers, keeled scrapers, end scrapers and backed blades are among the most common tool types. There is also some obsidian in the assemblages, mostly in the form of bladelets. However, as in the case of the Karanovo I sites, at all sites of the western group, including Aşağ 1 Pınar, there is a general deficiency of lithic tools. The featured Karanovo I blade is the only clear-cut made tool (Fig. 8), others being mostly ad hoc pieces. There is some obsidian at coastal sites, but it is completely absent from Aşağ 1 Pinar. The absence of developed lithic tools in the Thracian sites is rather astounding, as pressure-flaked bullet core technology with micro-blades occurs throughout Zone B.

Another striking difference is in the burial customs. As evidenced at Çatal Höyük in Central Anatolia, primary, secondary or collective intramural burials was a common practice in Zone A, but seldom in Zone B and almost absent from Zone D. On the other hand every site in Zone $\mathrm{C}$ has revealed large numbers of burials comparable to those of Zone A, the most abundant being at Ilıpınar, Pendik, Yenikapı and Aktopraklık (Figs. 9-10). With the exception of a few rather random scatters of bones, no burials have been recovered at any of the Thracian sites.

Clay figurines found in hundreds at almost every site in Zone B and D, including west Thracian ones, hardly exist at sites in Zone $\mathrm{C}$. The recovery of a wooden figurine at Yenikap1 (Fig. 11) suggests that wood might have been preferred to clay in eastern Marmara, but this does not exclude that wooden figurines might have been present in other regions and have not been recovered, as none had the conditions of preservation found at Yenikap1.

The scarcity of polished stone tools in eastern Marmara sites is interesting; well-finished celts or adzes occur, but in minimal numbers. Considering the wooded environment in which they lived, this also is strange. West Thracian sites, and particularly Aşağ1

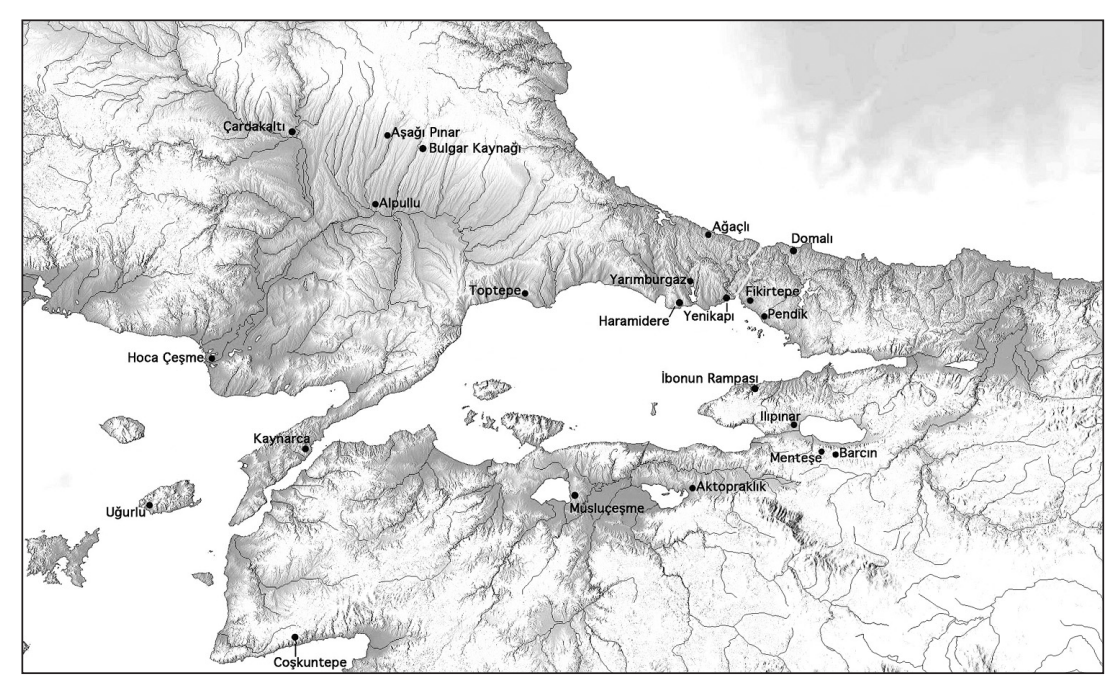

Fig. 6. Excavated Neolithic sites in the Marmara region. 
Pinar, have yielded vast amounts of polished stone tools of all sizes and shapes. Other particulars in comparing the two assemblages and, especially those related to pottery, can easily be seen in Figure 12; we will not go into details. Considering both the similarities, as well as the differences among the assemblages, simple explanations such as necessity or environmental concerns would not suffice to answer the question why. Nevertheless, knowing that at this stage a clear answer is not possible,
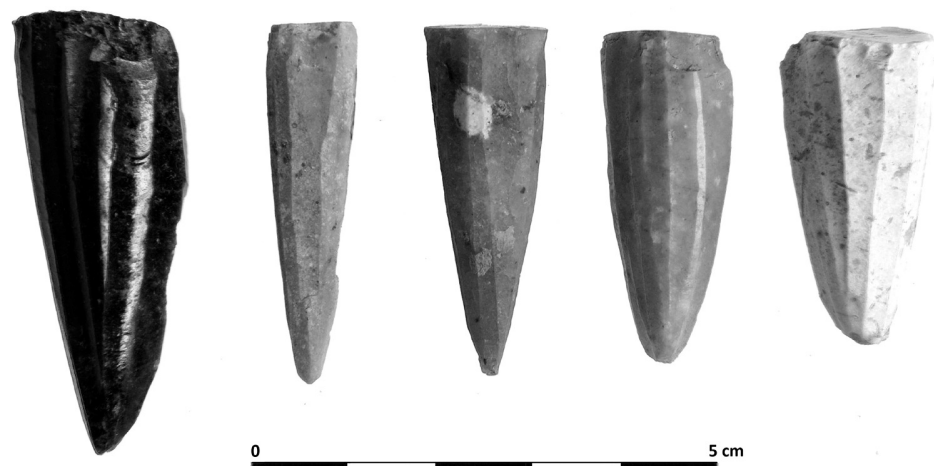

Fig. 7. Aktopraklh; bullet cores typical of the eastern Marmara Neolithic.

C do maintain the tradition. While the number of human burials that have been recovered at over 300 sites excavated in Zones B and D is less than a few dozen, the number of excavated skeletons is over 300 only at Pendik, Ilıpınar and Aktopraklık (Figs. 9-10). It thus seems plausible to surmise that groups of diverse origin, each having their particular social habits, were on the move. As we have already noted, we use this case to exemplify our trajectory in looking at Neolithic dispersal, being fully aware that much more data has still to be procured to draw a conclusive picture.

\section{Concluding remarks}

There has been an almost sudden inflow of new data coming from all over the Near East, Anatolia and Southeastern Europe, shaking the foundations of what we had taken to be the Neolithic. The picture emerging now is so different from the conventional one that some more time is still needed for it to settle in and de-contextualise in order to become part pens in the transition to the Pottery Neolithic period. On the other hand, intramural burial, primary, secondary or collective, was a widespread practice through the Pre-Pottery Neolithic period, but by the transitional period to the Pottery Neolithic intramural burials disappeared from the eastern parts of Zone A. Seemingly, burials occur in cemeteries that are not in the immediate vicinities of the settlements. In this respect, Central Anatolia stands out as an exceptional area, as evidenced at Çatal Höyük, where the tradition of intramural burials was sustained. What is of interest is that while communities moving westward to Zone $B$ did not bring with them the tradition of burying the dead within or nearby the settlement, those in Zone

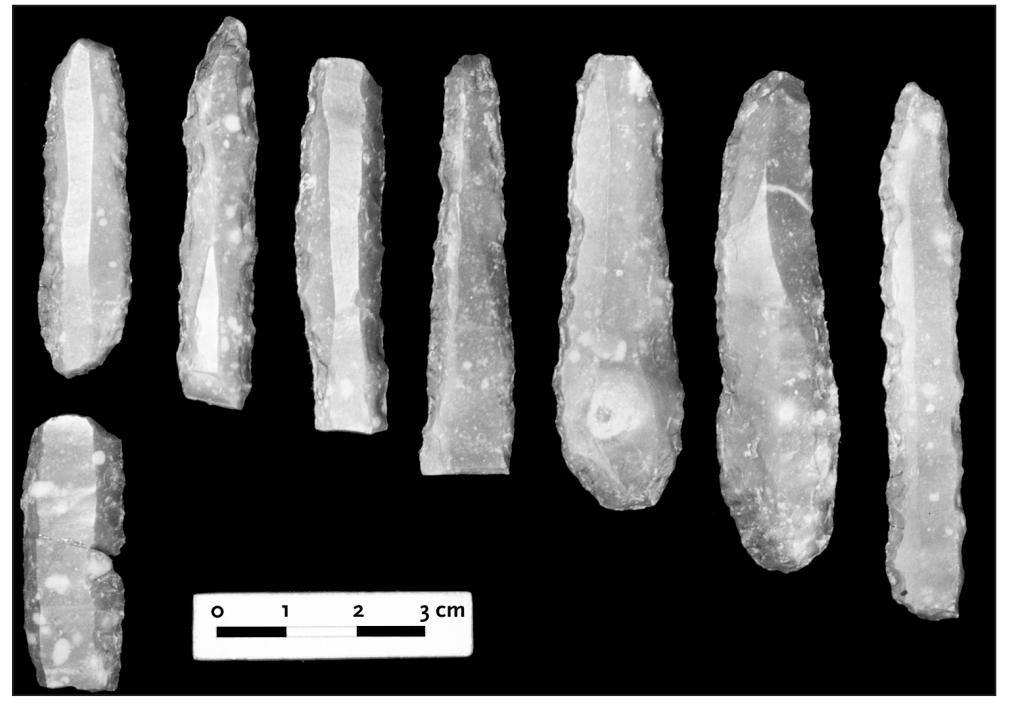

Fig. 8. So-called Karanovo I type blades from Hoca Çeşme. 
of new conceptual approaches. Only then will it be possible to adjust our perception of Neolithic identity. It is evidently not easy to avoid clichéd definitions that are so deeply rooted, and as already noted, more time is needed to develop a new way of looking at old problems. What we have presented in this paper is by no means conclusive and should be considered as a quest to develop new trajectories for approaching the problem. We tried to stress the primal difference between the core and periphery. Any discussion of problems related to the dispersal of the Neolithic way of life inevitably involves looking at a vast territory

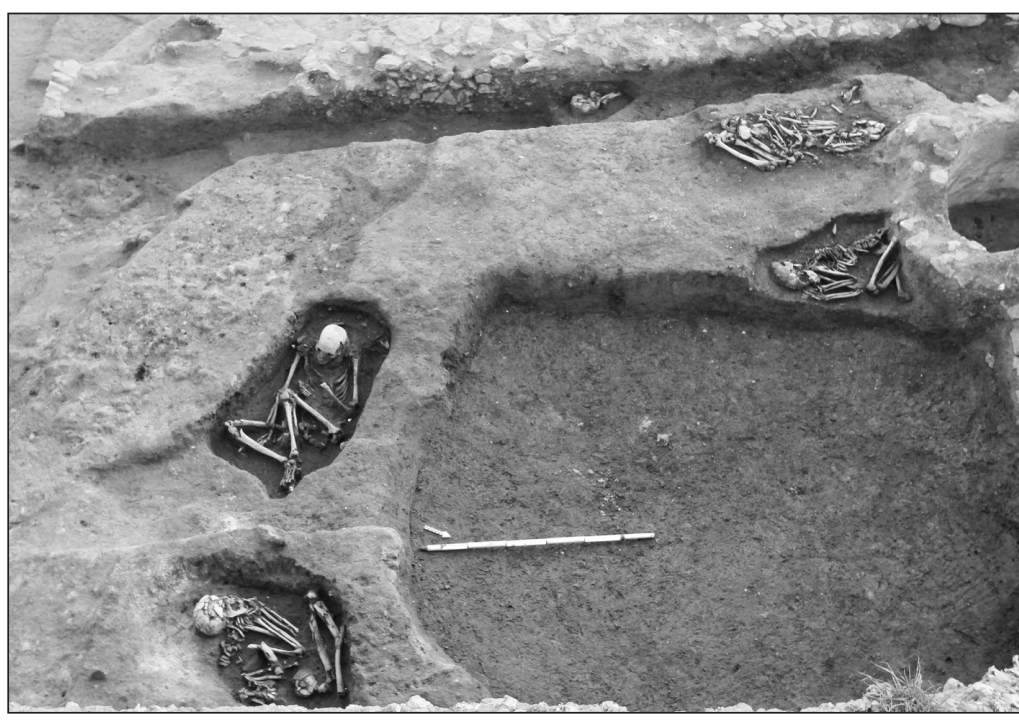

Fig. 9. Neolithic burials from the 2013 excavations at Pendik (courtesy of the Istanbul Archaeological Museums). through a supra-regional perspective. In this respect, narrowed over-specialisations are an obstruction, since to most of the archaeologists working in the core area, events that took place on the exterior at later dates are simply uninteresting. On the other hand, most colleagues working on regions of secondary or late Neolithisation, such as Europe or Central Asia, lack even a basic knowledge of the core area, as they are so much involved with the problems of their own regions. The contact zones on the borders of major cultural entities are generally overlooked, as their material evidence is atypical of neighboring regions, making it difficult to establish 'mental' bridges between the two areas. What is important is to maintain a delicate balance between over-simplistic generalisations and becoming lost in the details of the narrow confines of selective artefact typology; the latter obscures the overall picture by distracting the focus from the primary evidence to subsidiary issues. With these in mind, we conclude by noting certain traits that may help to develop supra-regional perspectives when examining the dispersal of the Neolithic way of life.

All of the components of the Neolithic package that are present in Zones B to $\mathrm{E}$ have antecedents in Zone $\mathrm{A}$, but in different ratios. An item that might be very rare in Zone A may turn out to be a common item or continue as a prestige object in any of the other zones. For example, 'bone spoons', 'festooned bone objects' and 'pintaderas' (Figs. 13-15) occur at random in some of the Pre-Pottery Neolithic assembla-
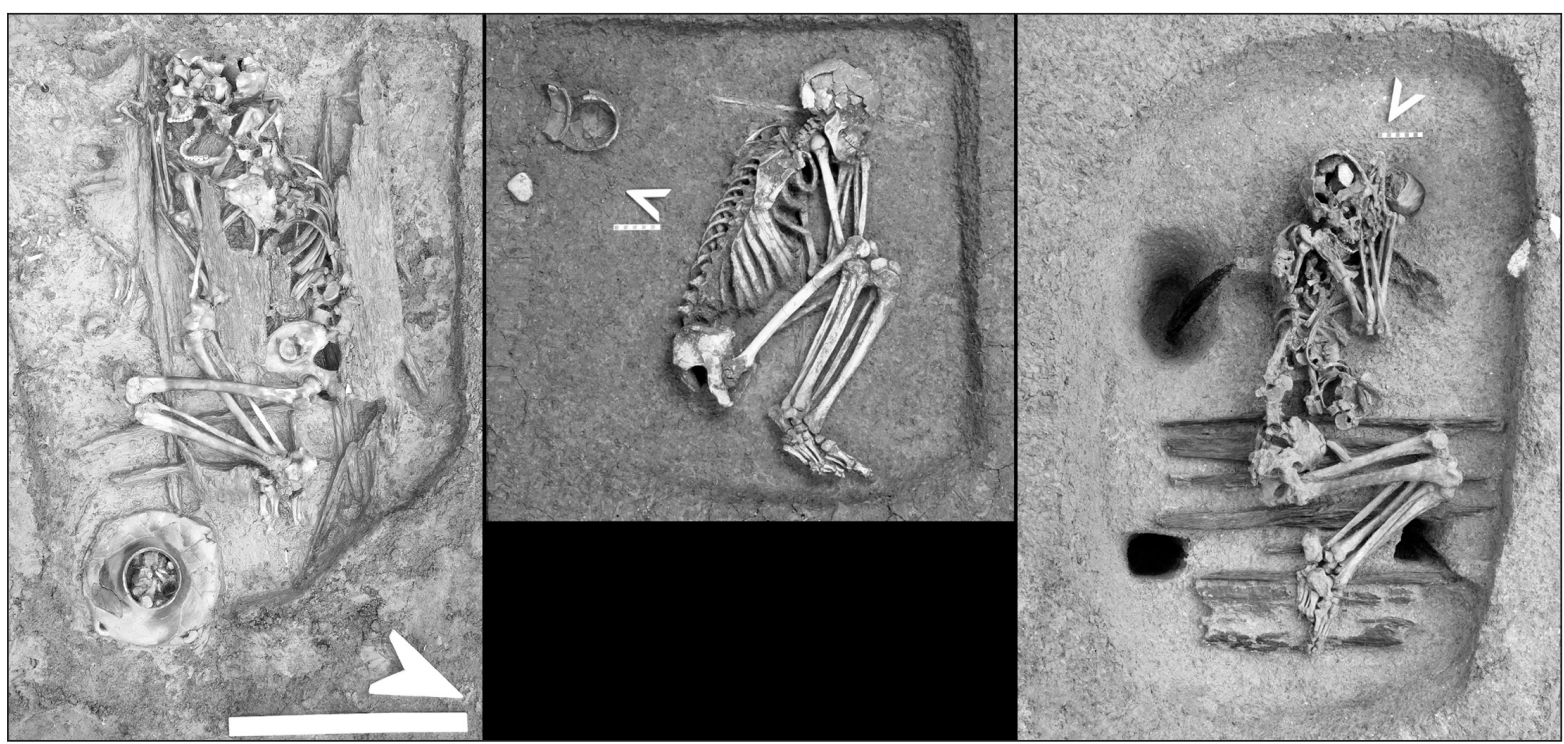

Fig. 10. A Neolithic burials from Yenikapn (courtesy of the İstanbul Archaeological Museums). 


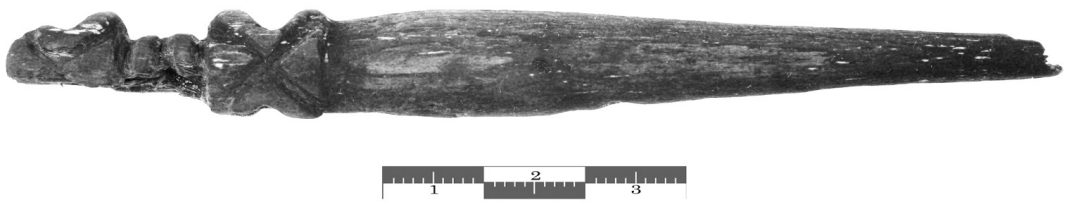

Fig. 11. Wooden Neolithic figurine from Yenikapr (courtesy of the Istanbul Archaeological Museums).

ges of Zone A, with no indication of being ranked as status objects. Bone spoons become a common commodity in Zones B, C and D, at the same time attaining a symbolic value as, at least in Zone $\mathrm{C}$, most are found among grave goods. On the other hand, 'pintaderas', which were so rare and insignificant during the Pre-Pottery stage, become exceedingly common with the onset of the Pottery Neolithic even in western parts of Zone A, then moved into Zones B and D, but not Zone C. 'Festooned bone objects', which are of insignificant occurrence in Zone B, are more common and varied in Zone D.

Items from Zone A that require an extremely high level of craftsmanship to manufacture occasionally occur in the earliest horizons of Zones $\mathrm{B}, \mathrm{C}$ or $\mathrm{D}$, but as poorly made imitations, possibly reflections of social memory. The so-called 'terrazzo' floor of the Pre-Pottery Neolithic, for example, occurs at some sites in Zone $B$ as red-coated lime floorings. Terrazzo floors at Pre-Pottery Neolithic $A$ and B sites such as Çayönü, Nevali Çori or Göbeklitepe located in the eastern wing of the core area were made by burning lime, which requires high technology, know-how and organised labor (Hauptmann, Yalcin 2000). Moving west, red-colored lime floorings become simpler, although in some cases such as Aş1kl, lime was being processed; the westernmost examples, those from Hac1lar, Ulucak, Hoca Çeşme III and Aşağ1 Pinar 8 , were made simply by setting pebbles in lime mortar and finishing with a red ochre coating. A similar case are stone bracelets: those of the Pre-Pottery period are highly sophisticated, decorated by grooves, ridges $e t c$., while those in Zones $\mathrm{B}$ and $C$ are still made of stone, but shaped as simple rings. In Zone $\mathrm{D}$, however, they are even simpler, being mostly made of clay (Fig. 16). Likewise, so-called altars or cult tables that are insignificant components of the Zone $\mathrm{A}$ and B pottery assemblages are the most common objects in Zones $\mathrm{C}$ and $\mathrm{D}$, being rectangular in the former and triangular in the latter (Fig. 17).

As noted above, the ancestral forms of all of the types that are present in Zones $\mathrm{B}$ to $\mathrm{E}$ are to be found in Zone A. However, the composition of the assemblages varies considerably from region to re-

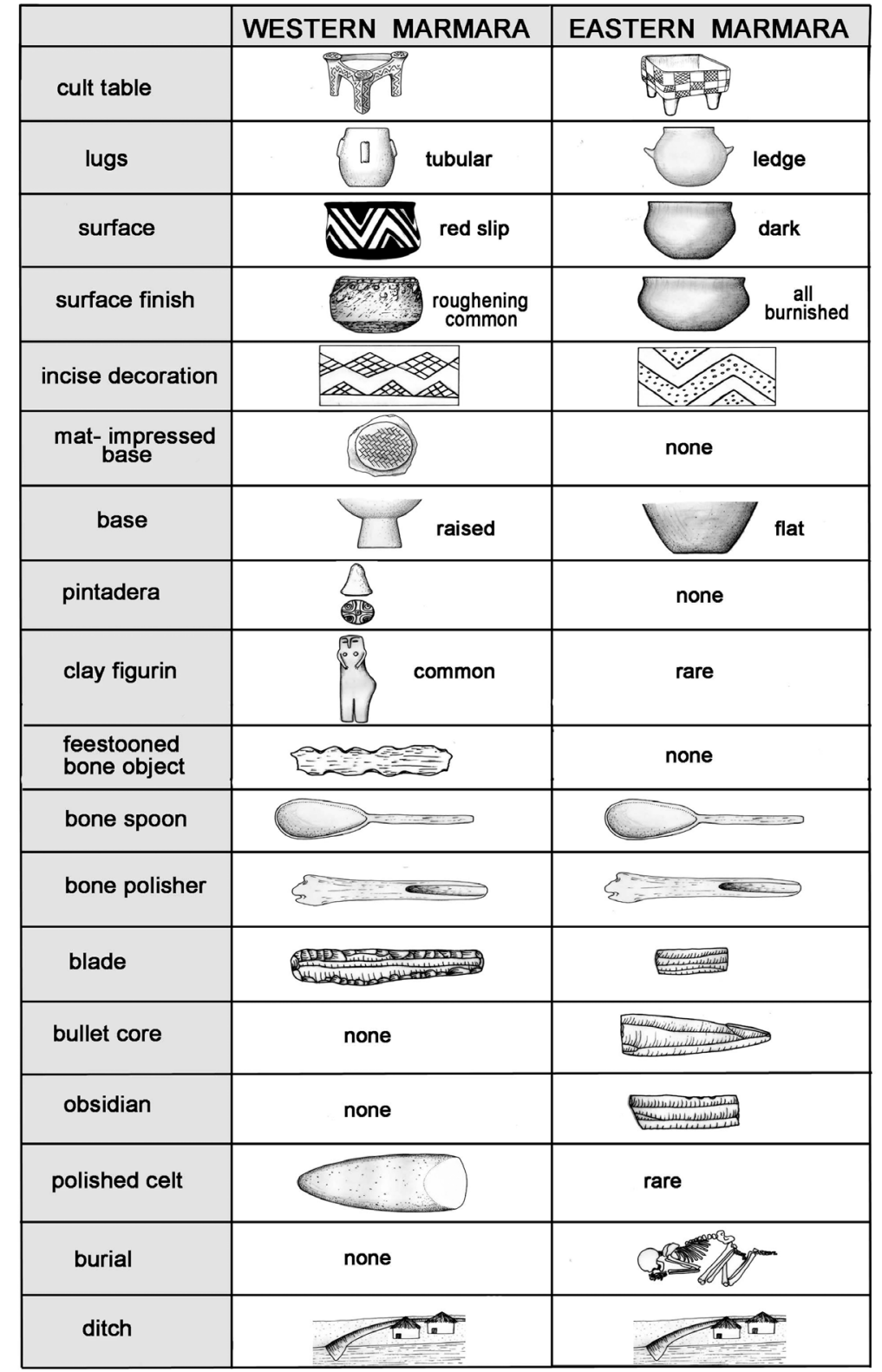

Fig. 12. Comparative table of east and west Marmara Neolithic assemblages. 


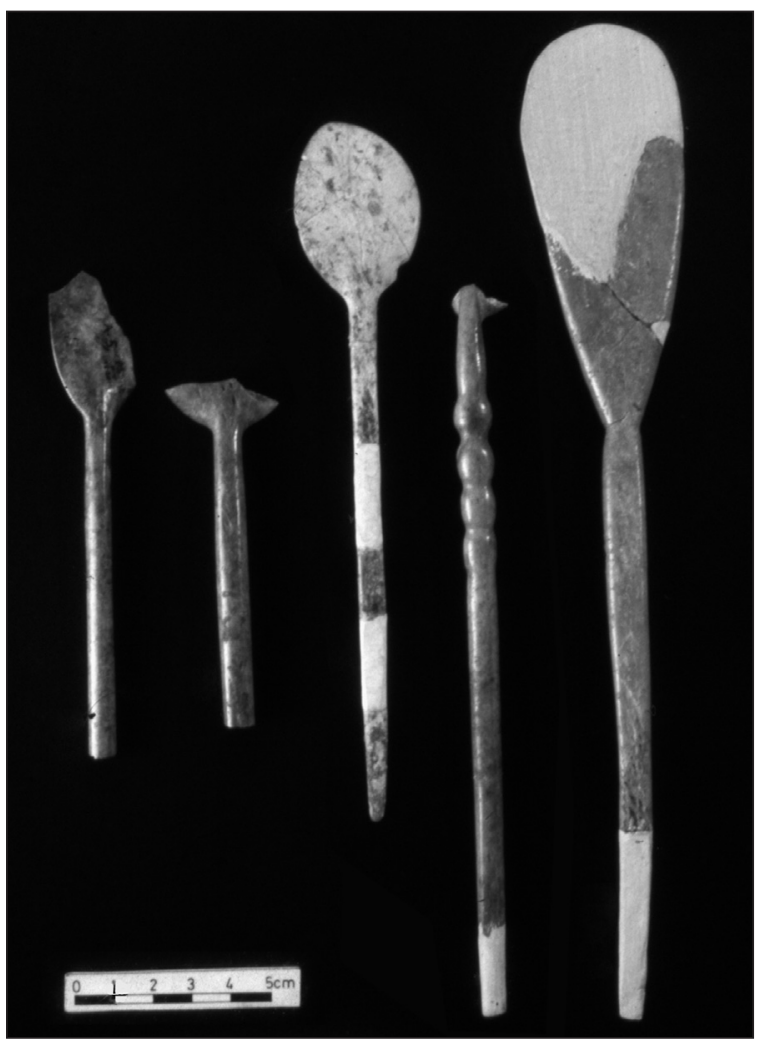

Fig. 13. Bone spoons from Fikirtepe and Pendik.

gion or even from site to site. In sorting out our list, we were able to find analogies to every item of Zones B to D somewhere in Zone A, but unevenly distributed. Thus, for example, analysing the material assemblage of a site in Thrace in search of similarities with Zone A, one item points to the Levant, another to Southeast Anatolia and still others to east Central Anatolia. The apparent mixed pattern of origins leads us to deduce the following.

It seems evident that the initial dispersal of the Neolithic way of life was due to a considerable demic movement beginning in the core area. The assessment of the Neolithic package in the new areas of Neolithisation clearly indicates that the antecedents of most objects that were transferred are in the eastern parts of the core area, in Northern Syria, the Levant and Southeastern Turkey, but not in Central Anatolia. Accordingly, the initial 'push' for migration must have originated from the eastern parts. What happened when this passed through Central Anatolia, where there was already a Pre-Pottery Neolithic sub-stratum, is not yet clear, but again, the Neolithic package that is found in the immediate contact
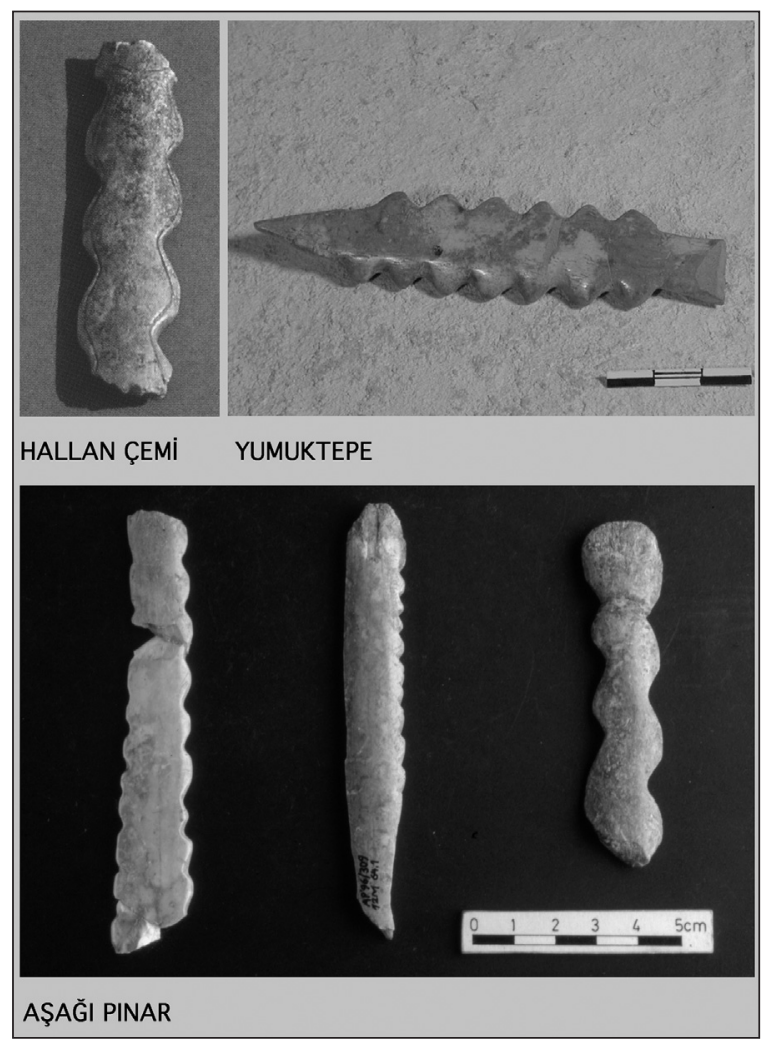

Fig. 14. Festooned bone objects.

zone in the western parts of Turkey suggests that they somehow merged. The various amalgamations of the Neolithic package imply that the movement to the west, at least in its earlier stages, was not an organised migration. On the contrary, the mixed or merged composition of the assemblages is highly suggestive of what we described elsewhere as the "segregated migration model" (Özdoğan 2008).

As we have noted before, the dispersal of the Neolithic way of life from the core to other regions was a multifarious event that lasted for more than a thousand years. In any time segment during this process, different modes of dispersal were taking place simultaneously. That is to say, while the most apparent

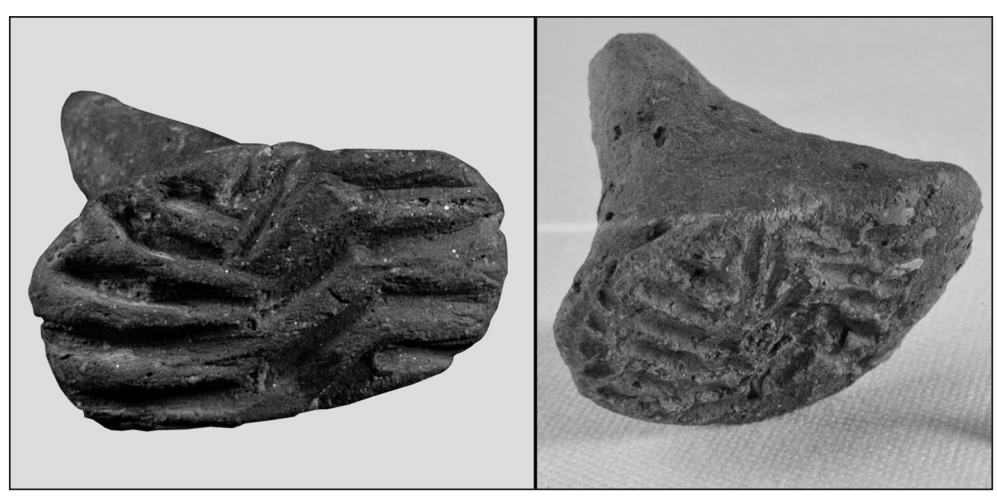

Fig. 15. Pintaderas. 


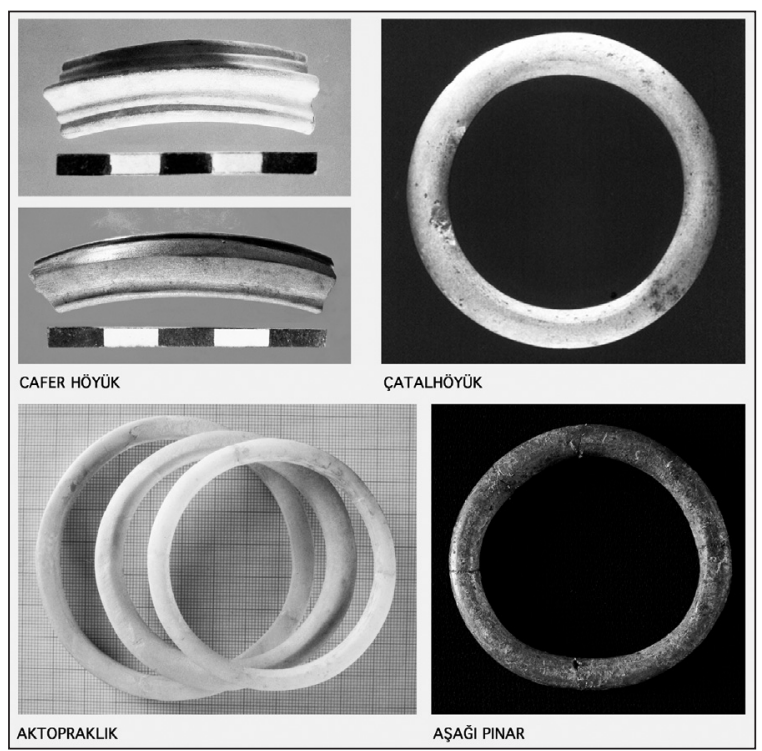

Fig. 16. Marble bracelets from Cafer Höyük in Southeast Anatolia, Catalhöyük in Central Anatolia, Aktopraklik in southern Marmara, and a clay bracelet from Aşağı Pınar-Eastern Thrace.

model was the segregated migration type, at the same time, direct migration, acculturation and/or transfer of know-how and technologies were also

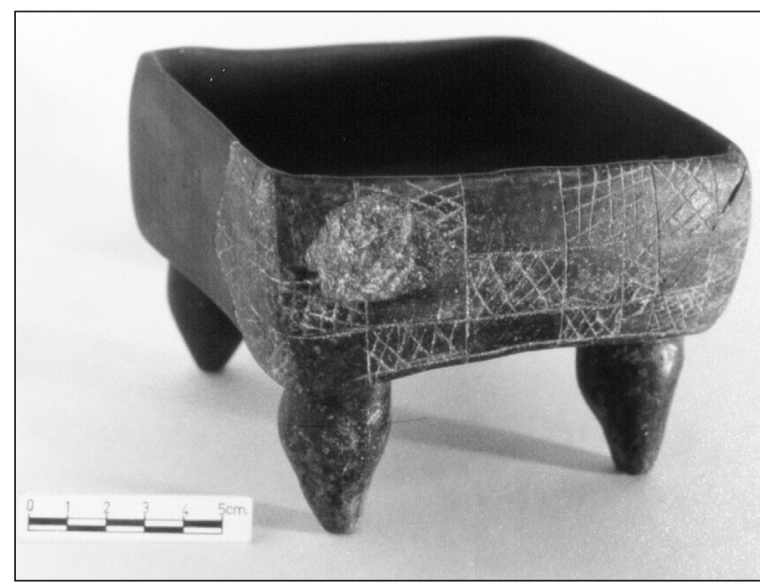

Fig. 17. A rectangular cult table from Fikirtepe.

taking place both by land and sea. It is also evident that further away from the core area, Neolithisation due to interaction or cultural contacts was more pronounced than any of the migratory models. The fact that all of the previous hypotheses on Neolithic dispersal - from migratory to autochthonous models were correct for each individual case, offers no way to finish the discussion at the present stage of our knowledge.

\section{References}

Anthony D. 1997. Prehistoric migration as social process. In J. Chapman, H. Hamerow (eds.), Migrations and Invasions in Archaeological Explanation. British Archaeological Reports IS 664. Archaeopress. Oxford: 21-32.

Bánffy E., Sümegi P. 2011. The environmental contexts of earliest Neolithic settlement and architecture in western Hungary. In A. Hadjikoumis, E. Robinson and S. Viner (eds.), The Dynamics of Neolithisation in Europe. Studies in honour of Andrew Sherratt. Oxbow Books. Oxford: 231-265.

Barford P. M. 2002. East is East and West is West? Power and paradigm in European archaeology. In P. F. Biehl, A. Gramsch and A. Marciniak (eds.), Archaeologies of Europe. History, Methods and Theories. Waxmann Münster. New York: 77-97.

Bar-Yosef 0. 2009. The collapse of the Levantine PPNB and its aftermath. In J. M. Burdukiewicz, K. Cyrek, P. Dyczek and K. Szymczak (eds.), Understanding the Past. Papers offered to Stefan K. Kozłowski. University of Warsaw. Warsaw: 29-35.
Bates D. G. 1973. Nomads and Farmers: A Study of the Yörük of Southeastern Turkey. The University of Michigan. Ann Arbor.

Bellwood P., Renfrew C. (eds.) 2002. Examining the Farming/Language Dispersal Hypothesis. McDonald Institute for Archaeological Research. Cambridge.

Bentley R. A. 2006. Academic copying, archaeology and the English language. Antiquity 80(307): 196-201.

Bocquet-Appel J. P., Bar-Yosef O. (eds.) 2008. The Neolithic Demographic Transition and its Consequences. Springer Science, Business Media. New York.

Bocquet-Appel J.P., Naji S., Vander Linden M. and Kozłowski J. 2009. Detection of diffusion and contact zones of early farming in Europe from the space-time distribution of ${ }^{14} \mathrm{C}$ dates. Journal of Archaeological Science 36: 807820 .

Bonsall C. 2007. When was the Neolithic transition in the Iron Gates? Societa Per La Preistoria e Protostoria Della Regione Friuli-Venezia Guilia 12: 53-66. 
Borić D. 1999. Places that created time in the Danube Gorges and beyond, c. 9000-5500 BC. Documenta Praehistorica 26: 41-70.

2011. Adaptations and transformations of the Danube Gorges foragers (c. 13,000-5500 BC): An overview. In R. Krauss (ed.), Beginnings - New Research in the Appearance of the Neolithic Between Northwest Anatolia and the Carpathian Basin (International Workshop, $8^{\text {th-9th }}$ April 2009, Istanbul). Verlag Marie Leidorf GmbH. Rahden/Westf: 157-203.

Budja M. 1993. The neolithisation of Europe. Slovenian aspect. Documenta Praehistorica 21: 163-193.

2004. The Neolithisation of the Balkans: Where in the puzzle?. In A. Lukes, M. Zvelebil (eds.), LBK Dialogues. Studies in the Formation of the Linear Pottery Culture. British Archaeological Reports IS 1304. Archaeopress. Oxford: 37-48.

Clare L. 2010. Pastoral Clashes: Conflict risk and mitigation at the Pottery Neolithic transition in the Southern Levant. Neo-Lithics 1(10): 13-31.

Clare L., Rohling E. J., Weninger B. and Hilpert J. 2008. Warfare in Late Neolithic/Early Chalcolithic Pisidia, Southwestern Turkey. Climate induced social unrest in the late $7^{\text {th }}$ millennium cal BC. Documenta Praehistorica 35: 65-92.

Colledge S., Conolly J. 2007. The Neolithisation of the Balkans: A Review of the archaeobotanical evidence. Societa Per La Preistoria e Protostoria Della Regione Friuli-Venezia Guilia 12: 25-38.

Danışmaz H. 2012. Urartu Krallı̆ğ ile Assur Arasındaki Siyasi Ilisskiler. Unpublished MA thesis. University of Marmara. İstanbul.

Gatsov I. 2001. Epipaleolithic/ Mesolithic, Neolithic period chipped stone assemblages from Southern Bulgaria and North West Turkey: Similarities and differences. Türkiye Bilimler Akademisi Arkeoloji Dergisi (TÜBA-AR) 4: $101-112$

2003. The latest results from the technological and typological analysis of chipped stone assemblages from Ilipinar, Pendik, Fikirtepe and Menteşe, NW Turkey. Documenta Praehistorica 30: 153-158.

Goring-Morris N., Belfer-Cohen A. 2010. "Great expectations", or the inevitable collapse of the Early Neolithic in the Near East. In M. S. Bandy, J. R. Fox (eds.), Becoming Villagers: Comparing Early Village Societies. The University of Arizona Press. Arizona: 62-77.
Harris R. D. 2003. Paradigms and transitions: reflections on the study of the origins and spread of agriculture. In A. Ammerman, P. Biagi (eds.), The Widening Harvest. The Neolithic Transition in Europe: Looking Back, Looking Forward. Archaeological Institute of America. Massachusetts: $43-58$.

Hauptmann A., Yalçın Ü. 2000. Lime plaster, cement and the first puzzolanic reaction. Paléorient 26 (2): 61-68.

Hütteroth W. D. 1959. Bergnomaden und Yaylabauern im mittleren Kurdischen Taurus. Im Selbstverlag des Geographischen Institutes der Universität Marburg. Marburg.

Kızıltan Z. 2013. Pendik Höyük Kazıları. Aktüel Arkeoloji 34: 32-36.

Oross K., Bánffy E. 2009. Three successive waves of Neolithisation: LBK development in Transdanubia. Documenta Praehistorica 36: 175-189.

Özdoğan M. 1995. Neolithization of Europe: A view from Anatolia. Part 1: The problem and the evidence of East Anatolia. Poročilo o raziskovanju paleolitika, neolitika in eneolitika $v$ Sloveniji 22: 25-61.

1997. The Beginning of Neolithic economies in Southeastern Europe: An Anatolian perspective. Journal of Eropean Archaeology 5/2: 1-33.

2002. Redefining the Neolithic of Anatolia. In R. Cappers, S. Bottema (eds.), The Dawn of Farming in the Near East. Ex Oriente. Berlin: 153-159.

2004. Heritage and Nationalism in the Balkans and Anatolia or changing patterns, what has happened since Hasluck? In D. Shankland (ed.), Archaeology, Antropology and Heritage in the Balkans and Anatolia: The Life and Times of F. W. Hasluck, 18781920. ISis Press. Istanbul: 389-405.

2008. An alternative approach in tracing changes in demographic composition: the westward expansion of the Neolithic way of life. In J. Bocquet-Appel, O. BarYosef (eds.), The Neolithic Demographic Transition and its Consequences. Springer. Heidelberg: 139-178.

2010a. The transition from round-plan to rectangular. In D. Gheorghiu (ed.), Neolithic and Chalcolithic Architecture in Eurasia. Techniques and Spatial Organisation. British Archaeological Reports IS 2097. Archaeopress. Oxford: 29-34.

2010b. Westward expansion of the Neolithic way of life: Sorting the Neolithic package into distinct packages. In P. Matthiae, F. Pinnock, L. Nigro and N. Mar- 
chetti (eds.), Near Eastern Archaeology in the Past, Present and Future. Heritage and Identity. Proceedings of the ICAANE 6. Harrassowitz Verlag, Wiesbaden Vol 1: 883-897.

2011a. Archaeological evidence on the westward expansion of farming communities from Eastern Anatolia to the Aegean and the Balkans. Current Anthropology 52: 415-430.

2011b. Submerged sites and drowned topographies along the Anatolian coasts: an overview. In J. Benjamin, C. Bonsall, C. Pickard and A. Fischer (eds.), Submerged Prehistory. Oxbow Books, 0xford: 219-229.

2012. An Anatolian perspective on the Neolithization process in the Balkans. New questions, new prospects. In R. Krauß (ed.), Beginnings - New Research in the Appearance of the Neolithic Between Northwest Anatolia and the Carpathian Basin. Verlag Marie Leidorf GmbH. Rahden/Westf: 23-33.

2013a. Anatolia and the Balkans: archaeology. In I. Ness, P. Bellwood (eds.), The Encyclopedia of Global Human Migration. Volume I. Wiley-Blackwell. Hoboken, New Jersy: 139-145.

2013b. Neolithic sites in the Marmara Region. Fikirtepe, Pendik, Yarımburgaz, Toptepe, Hoca Çeşme and Așağı Pınar. In M. Özdoğan, N. Başgelen and P. Kuniholm (eds.), The Neolithic in Turkey. New Excavations \& New Research, Vol. 5: Northwestern Turkey and Istanbul. Archaeology and Art Publication. İstanbul: 167-269.

2014. The Neolithic Collapse or the Transition from PPN to PN. In B. Finlayson, C. Makarewicz (eds.), Settlement, Survey and Stone. Essays on Near Eastern Prehistory in Honour of Garry Rollefson. Ex oriente, Berlin in collaboration with the CounBritish Research in the Levant, London (2014): 169-175.

Özdoğan M., Başgelen N. and Kuniholm P. (eds.) 2013. The Neolithic in Turkey. New Excavations \& New Research, Vol. 5: Northwestern Turkey and Istanbul. Archaeology and Art Publication. Istanbul.

Özkaya V., Coşkun A. and Soyukaya N. 2013. Körtik Tepe. Diyarbakır Valiliği. İstanbul.

Perlès C. 2005. From the Near East to Greece: let's reverse the focus - cultural elements that didn't transfer. In C. Lichter (ed.), How Did Farming Reach Europe? Anatolian-European Relations from the Second Half of the $7^{\text {th }}$ Through the First Half of the $6^{\text {th }}$ Millennium cal BC. Byzas 2. Ege Yayınları. İstanbul: 275-290.
Pinhasi R. A. 2003. New model for the spread of the first farmers in Europe. Documenta Praehistorica 30: 1-47.

Price D. 2000. Europe's first farmers: an Introduction. In D. Price (ed.), Europe's First Farmers. Cambridge University Press. Cambridge: 1-18.

Richards M. 2003. The Neolithic transition in Europe: archaeological models and genetic evidence. Documenta Praehistorica 30: 159-167.

Rollefson G. O., Köhler-Rollefson I. 1989. The collapse of Early Neolithic settlements in the Southern Levant. In I. Hershkovitz (ed.), Change, People and Culture. British Archaeological Reports IS 508. Archaeopress. Oxford: 73-89.

Sherratt A. 1997. Changing perspectives on European prehistory. In A. Sherrat (ed.), Economy and Society in Prehistoric Europe. Edinburgh University Press. Edinburgh: 1-34.

2004. Fractal farmers: patterns of Neolithic origin and dispersal. In J. Cherry, C. Scarre and S. Shennan (eds.), Explaining Social Change: Studies in Honor of Colin Renfrew. Cambridge University Press. McDonald Institute Monographs. Cambridge: 53-63.

Tringham R. 2000. Southeastern Europe in the transition to agriculture in Europe: bridge, buffer, of mosaic. In T. D. Price (ed.), Europe's First Farmers. Cambridge University Press. Cambridge: 19-56.

Watkins T. 1990. The origins of house and home? World Archaeology 21(3): 336-347.

1996. The Origins of the Household in North Mesopotamia. Nederlands Historisch-Archaeologisch Instituut te Istanbul. Leiden.

2012. Household, Community and Social Landscape: Maintaining Social Memory in the Early Neolithic of Southwest Asia. Verlag Dr. Rudolf Habelt GmbH. Bonn.

Weninger B. and 18 authors. 2009. The impact of rapid climate change on prehistoric societies during the Holocene in the Eastern Mediterranean. Documenta Praehistorica 36: 7-59.

Zvelebil M. 2002. Demography and dispersal of early farming populations at the Mesolithic-Neolithic transition: lingustic and genetic implications. In P. Bellwood, C. Renfrew (eds.), Examining the Farming/Language Dispersal Hypothesis. McDonald Institute for Archaeological Research. Cambridge: 379-394.

2005. Looking back at the Neolithic transition in Europe. European Journal of Archaeology 8(2): 183-190. 
